\title{
二つの静止衛星と地上波のテレビジョン放送を用いた測位システム
}

\author{
韋 瑋 *. 安田 明生 ** \\ 山下 晃司 ${ }^{* *} \cdot$ 川村 雅志 ${ }^{* *}$
}

\section{Positioning System Using Three TV Broadcasting Waves from Two Geostationary Satellites and Tokyo Tower}

\author{
Wei WEI, Akio YASUDA, Kohji YAMASHITA and Masashi KAWAMURA
}

\begin{abstract}
As a step to developing a regional positioning system using geostationary satellites, the authors tried to deduce the positions of a ship steaming in Tokyo Bay, by three transmitters of TV signals ; two geostationary satellites, BS $\left(110^{\circ} \mathrm{E}\right)$ and Super Bird $\left(162^{\circ} \mathrm{E}\right)$ and Tokyo Tower $\left(139.75^{\circ} \mathrm{E}\right.$, $\left.35.67^{\circ} \mathrm{N}\right)$. They keep transmitting TV programs. The high stability of the synchronous pulses in the video signal makes it possible to find a range accurately. The rms error of 240 positions of a ship navigating up Uraga Channel deduced every second in reference to those by GPS is $8.7 \mathrm{~m}$ in longitudinal direction and $6.4 \mathrm{~m}$ in latitudinal one. Since the longitudinal error is $2.9 \mathrm{~m}$, as it was observed at a fixed point (Tokyo University of Mercantile Marine), we suspect that the GPS positions might have been modified by the Kalman filter.
\end{abstract}

\section{1. まえがき}

人工衛星を用いた移動体の測位システムは世界各国で様々な提案および開発がなされている。GPS は周 回衛星を用いた全世界的な測位システムで広く普及しているが、米軍の管理下にあるので、バックアップ システムとして静止衛星を用いた局地的な測位システムの研究がなされている(1122。筆者らはテレビジョ ンの映像同期信号が高安定なルビジュウム $\left(R_{b}\right)$ 発振器を基準に作られていること、その伝送に伝搬状態 が安定な、地上波では VHF 電波を、衛星放送では $12 \mathrm{GHz}$ 帯を用いていることから、これらを用いた高 精度の測位システムの開発を試みだ）。今回は、前報のVHF (東京タワー)とBS の組み合わせに、最近 放送を開始したCS を加えることにより、3つの送信源を用いてシステムの拡張をはかった。すなわち $\mathrm{VHF}$ を基準にとれば従来用いていた $\mathrm{R}_{\mathrm{b}}$ 基準発振器を必要としない。また $\mathrm{R}_{\mathrm{b}}$ 発振器を用いれば測位可能 領域を BS, CS の受信可能領域まで大幅に拡張できる。

ここでは、二つの静止衛星と地上波のテレビジョン放送波を用いた測位システムの実験の概要と実験の 結果について述べる。

\section{2. 測位実験システムの概要}

図 1 は移動体測位実験の概念図である。3つの送信源からの TV 放送波を用いている。測距用のパルス として、送信源からの映像同期信号中の奇数フィールドの垂直帰線消去期間中のライン 11 番目の前の水 平同期パルスを抜き取っている(4)。このパルスの周波数は正確に $30 / 1.001 \mathrm{~Hz}$ である。東京タワーからの

* 学生会員 東京商船大学大学院 (干135 東京都江東区越中島 2-1-6)

**正 会 員 東京商船大学 (厂135 東京都江東区越中島 $2-1-6$ ) 
VHF テレビジョンの測距パルスを基準に BS とCS からの測距パルスの到達遅れ時間を測定することによ り、BS と東京タワー、CS と東京タワーの距離差を正確に測定でき、おの抢のを焦点とする 2 つ双曲面 が得られ(5)、それらと地球表面との交点から位置を求めることができる。一方、静止衛星自身の位置の変 動を補正するために、東京商船大学を監視地点としてVHF を基準に BS と CS からの測距パルスの到達 遅れ時間の変動を観測して、衛星位置の変動を監視している。

それぞれの測距パルスは周波数安定度は高いが、互いに同期していないので、実測されるデー夕は距離 の変化分である。従って、現状では絶対距離を求めるのに初期位置が必要である。

図 2 は測位可能領域における BS と東京タワーの距離差が $30 \mathrm{~km}$ 毎の位置の線と CS と東京タワーの距 離差が $30 \mathrm{~km}$ 毎の位置の線である。東京タワーからの電波の到達距離は約 $90 \mathrm{~km}$ である。東京湾や相模湾 では、位置の線の交角はそれほど悪くはなく、高精度の測位が期待できる。

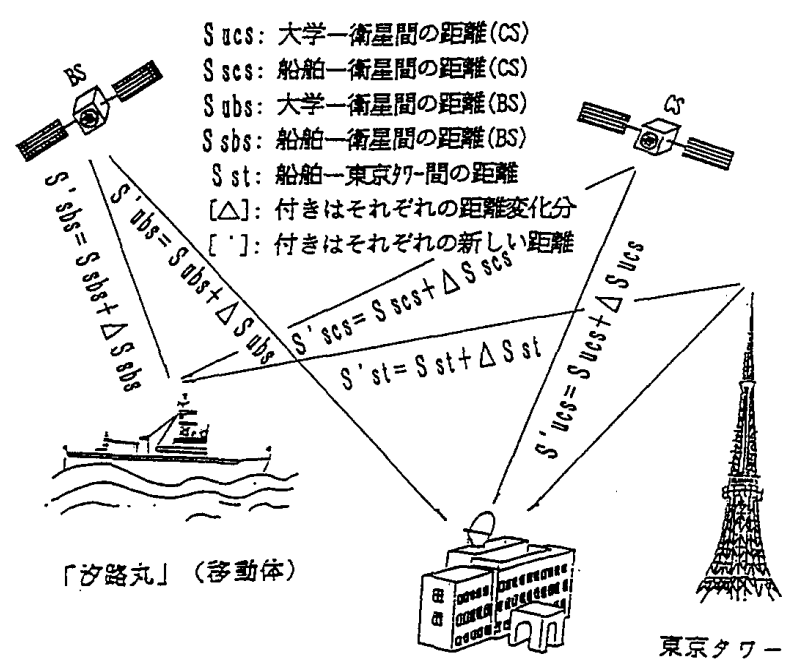

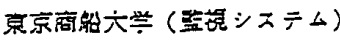

図 1 移動体測位実験の概念図

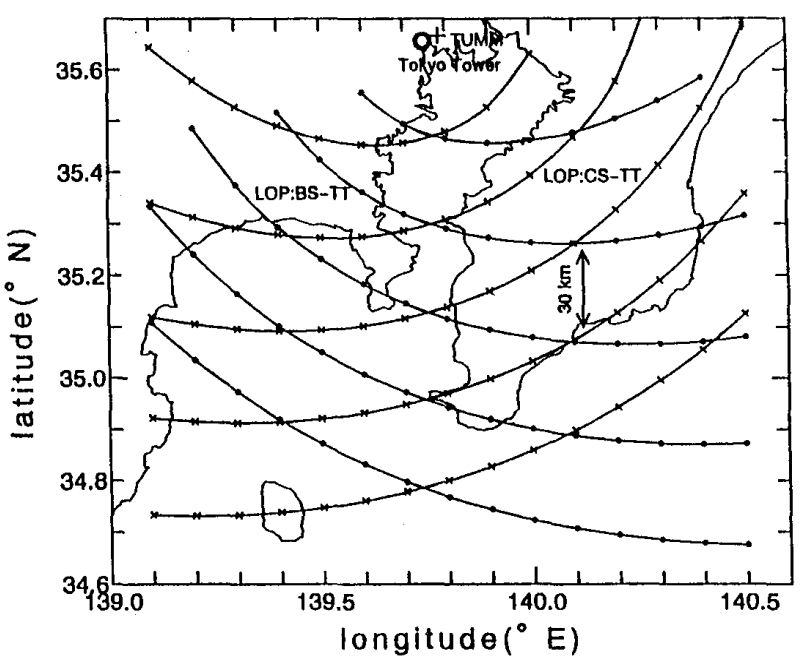

図 2 測位可能領域図と位置の線

\section{3. 測位実験装置}

図 3 は [汐路丸] に拈ける測距システムのブロック図である。BS は汐路丸に搭載されている JRC 製の 自動追尾アンテナで、CS は自作の追尾アンテナ(6) で、また VHF は無指向性のターンスタイルアンテナで 受信した。 $\mathrm{R}_{\mathrm{b}}$ 基準発振器からの $100 \mathrm{kHz}$ の基準信号を乗算回路で $3 / 10010$ 倍することにより、測距パルス と正確に同期する基準パルスを作り、時間差パルス発生回路＃1，\#2，\#3の start 端子に同時に入力す る。BS, CS, VHF の各アンテナにより受信された信号は、おのおののチューナーで復調される。測距パ ルス抜き取り回路で抜き取った測距パルスを時間差パルス発生回路の stop 入力端子に加えることにより、 BS, CS，VHF のそれぞれの到達遅れ時間に相当する時間差パルスが作られる。これらを各ゲートに加え

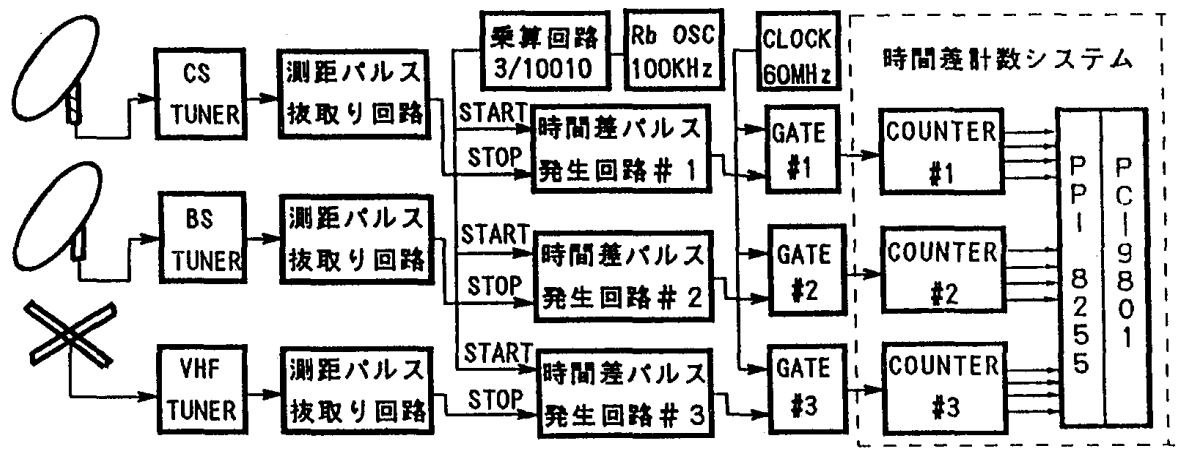

図 3 「汐路丸」における測距システムのブロック図 
$60 \mathrm{MHz}$ のクロックパルスを計数することにより距離差の変動分が求められる。時間差計数システムは 3 組の高速カウンターとPPI-8255 からなり、おのおの毎秒 10 データずつパーソナルコンピュータに取り込 んでいる。1 カウントは $5 \mathrm{~m}$ の距離変化に相当する。

東京商船大学における衛星監視システムでは、 $\mathrm{R}_{\mathrm{b}}$ 発振器の代わりにVHF の湘距パルスを基準にして、 $\mathrm{BS}$ と CSのおのおのの測距パルスの到達時間差を測定することにより、各衛星の位置の変動を観測して いる。 2 系統の時間差計测なので、おのおの毎秒 15 データずつ収集している。1 カウントあたり $2.5 \mathrm{~m} の$ 衛星移動距離に相当する。

\section{4. 実験の過程}

実験は平成 5 年 3 月 9 日から 11 日にわたり、東 京湾において汐路丸上で行った。 $R_{\mathrm{b}}$ 発振器からの 基準パルスに対して $\mathrm{BS}, \mathrm{CS}$, 東京タワーからの測 距パルスの遅れ時間を 1 秒毎に 10 データずつ収集 した。同時にGPS 受信機 (MX-4200, Magnavox) の 1 秒毎の测位データも収集した。なお、測位は BS と東京タワー、CS と東京タワーを対とする双曲 線航法方式で行ったので、東京タワーからの測距パ ルスを基準とするデータに変換している。

監視地点の東京商船大学では同日、東京タワーか らの VHF の测距パルスを基準にして BS, CSから の測距パルスの到達遅れ時間を毎秒 15 データずつ 収集した。図 4 は 3 月 11 日午前 9 時から約 7 時間 にわたって観測した到達遅れ時間の変動を示す。 BS は 24 時間周期で変動しているように見え、大体

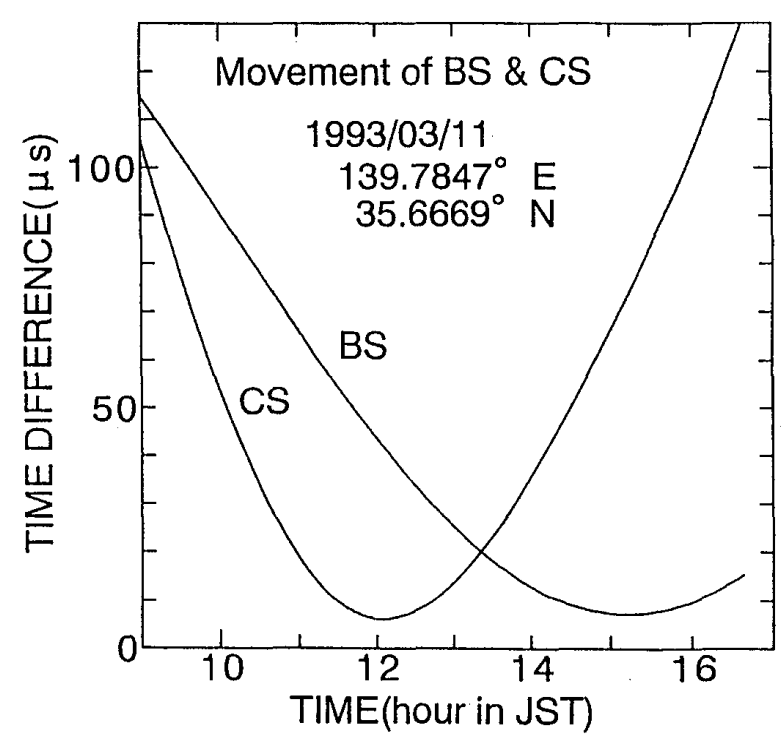

図 4 衛星 (BS-3b，スーパーバード-B) の変動図 1/4 周期分が観測されているとすると、当日は 1 日で最大 $30 \mathrm{~km}$ 変動していたことがわかる。

現在のところ商船大学と汐路丸の間でリアルタイムのデータ回線をもたないので、測位計算はデータを 商船大学に持ち帰って行った。

測位計算にあたっては、1秒間のデータ（監視データでは 15 個，移動体における測距データでは 10 個） を平均したものを用いた。ただし、連続したデータで 2 カント以上ジャンプしたものは除いた。

\section{5. 測位計算}

位置の決定は BS と東京タワー、CS と東京タワーの距離差一定の 2 本の位置の線の交点を求めること によって行った。はじめにBS と東京タワーの位置の線の求め方を説明する。

図 1 の概念図で、観測地の東京商船大学で、VHFを基準にして BS からの測距パルスの到達遅れ時間 を測定することにより、時間差変化分 $\Delta T_{u b s}$ が得られる。現在のところ、衛星までの絶対距離の测定はで きないので、以下の計算においては、初期値において衛星高度 $H_{b s}$ を $35810 \mathrm{~km}$ とし、衛星までの距離を 求めて $S_{u b s}$ とした。衛星までの新しい距離 $S^{\prime}{ }_{u b s}$ は $c$ を光速とすると

$$
\begin{aligned}
S^{\prime}{ }_{u b s} & =S_{u b s}+\Delta S_{u b s} \\
& =S_{u b s}+c\left(\Delta T_{u b s} / 2\right)
\end{aligned}
$$

で求められる。また BS が東経 $110^{\circ}$ の赤道上空に位置するとし、距離変化が高度変化のみで生じるとし、 地球を半径 $r$ の球体と仮定する。観測地東京商船大学の緯度 $L_{a}$, 経度 $L_{o}$ を原点とする、衛星 BS の位置 $\left(x_{u b s}, y_{u b s}, z_{u b s}\right)$ は

$$
\begin{aligned}
& x_{u b s}=-\left(H_{b s}+r\right) \sin \left(L_{o}-110^{\circ}\right) \\
& y_{u b s}=-\left(H_{b s}+r\right) \cos \left(L_{o}-110^{\circ}\right) \sin \left(L_{a}\right) \\
& z_{u b s}=\left(H_{b s}+r\right) \cos \left(L_{o}-110^{\circ}\right) \cos \left(L_{a}\right)-r
\end{aligned}
$$


となる。衛星高度として初期值を与え、衛星までの計算距離 $D_{u b s}$

$$
D_{u b s}=\sqrt{x_{u b s}{ }^{2}+y_{u b s}{ }^{2}+z_{u b s}{ }^{2}}
$$

を求め、観測距離 $S^{\prime}{ }_{u b s}$ と計算距離 $D_{u b s}$ が等しくなるように $H_{b s}$ を变えて綝り返し計算を行い、衛星の新し

い絶対高度が得られる。

つぎに移動体において GPS で求めた初期位置 $\left(l_{a}, l_{o}\right)$ を移動体の原点とすると、初期位置から衛星( BS) までの距離 $S_{s b s}$ と東京タワーまでの距離 $S_{s t}$ が求められ、距離差 $S_{t b s}$ が求められる。受信点で VHF を基準 にBS からの測距パルスの到達遅れ時間の変化分 $\Delta T_{t b s}$ が測定される。これは衛星の移動之移動体の移動 によって生じるもので、新しい距離差 $S^{\prime}{ }_{t b s}$ は $c$ を光速とすると

$$
S^{\prime}{ }_{t b s}=S_{t b s}+c\left(\Delta T_{t b s}\right)-c\left(\Delta T_{u b s} / 2\right)
$$

で求められる。右辺第 3 項は衛星の高度変化による時間差変動の補正で、 $S^{\prime}{ }_{t b s}$ は移動体における新しい衛 星位置と東京タワーからの距離差である。現在の位置の経度から微小経度差 $\pm \Delta l$ の 2 本の経線上でそれ ぞれ適当な緯度の值を用い(2) (3) (4) (5) 式により、BS までの距離と東京タワーまでの距離の差 $D_{t b s}$ が求ま り、それが観測距離差 $S^{\prime}{ }_{t t s}$ に等しくなるように緯度の值を変えて繰り返し計算し、それぞれの経度の値に 対する緯度の值が求められる。これら 2 点を通る直線が BS と東京タワーからの距離差一定の位置の線と なる。

CS に対してはその位置を東経 $162^{\circ}$ とし、BS の場合と同様にCS と東京タワーからの距離差一定の位置 の線を求めることができる。

以上で求めた 2 本の位置の線の交点から、測定值を満足する新しい位置を決定できる。

新しい位置を現在位置として、以上の過程を繰り返すことにより、次々に刻々の位置を求めることがで きる。

ただし、衛星までの距離変化が高度変化のみによって生じるとする仮定は厳密には正しくない。しかし ながら、今回の測位位置とモニタ一地点の距離が衛星までの距離に比べて非常に小さいので、大きな誤差 は生じないであろう。まだ、電離層や対流圈による影響もモニタ地点に対するあのとほとんど同一と考え られ、それらの影響は無視できる。ジオイドについてもここでは考慮していない。

\section{6. 測位結果と検討}

初めに测位精度評価のために、東京商船大学における定点で測位を試みた結果を示す。図 5 は東京商船 大学 (TUMM) 付近での位置の線の様子を示す。LOP : BS - TT と LOP : CS - TT はそれぞれ BS と東京 タワー (TT)、CS と東京タワーの距離差一定の位置の線である。図から位置の線の交角が小さく高精度 の測位が期待できないことがわかる。

図 6 は 100 秒間の測位結果を示す。緯度方向に大きく分散し、標準偏差は経度方向で $2.89 \mathrm{~m}$ 、緯度方向 で $14.5 \mathrm{~m}$ である。図中の枠は測距装置の分解能 $\pm 5 \mathrm{~m}$ に扔ける位置の線を示すが、特にBS と東京タワー の位置の線は大きくシフトし、枠が縦長になることから、枠内に表示された測位結果が合理的であること がわかる。

図 7 は 3 月 11 日の帰りの航海における浦賀水道付近の航跡図を示す。GPS の 1 秒毎の測位点と比較し て表示している。GPSによる測位点を基準に取ると標準偏差は経度方向で $8.7 \mathrm{~m}$ 、緯度方向で $6.4 \mathrm{~m}$ であ る。図 8 に初期の部分の拡大図で 40 秒間の航跡を示す。

図 9 は測位地点付近の $\pm 5 \mathrm{~m}$ 毎の位置の線である。図から見ると経度方向に分布が広がるのは合理的で あると考えられる。定量的な評価は行っていないので、断定はできないが、定点の観測結果の標準偏差と 比較すると誤差が大きすぎるように思われる。ここで航跡図をよくみると必ずしもGPS の航跡からラン ダムにずれているのではなく、GPS の航跡にからんでいるように見える。GPS はこの日はSA がかかっ ていたということであるが、このようにほとんど直線的な航跡が描かれている事を考えると、GPS の測 位位置にも問題があるのではないかとも考えられる。 


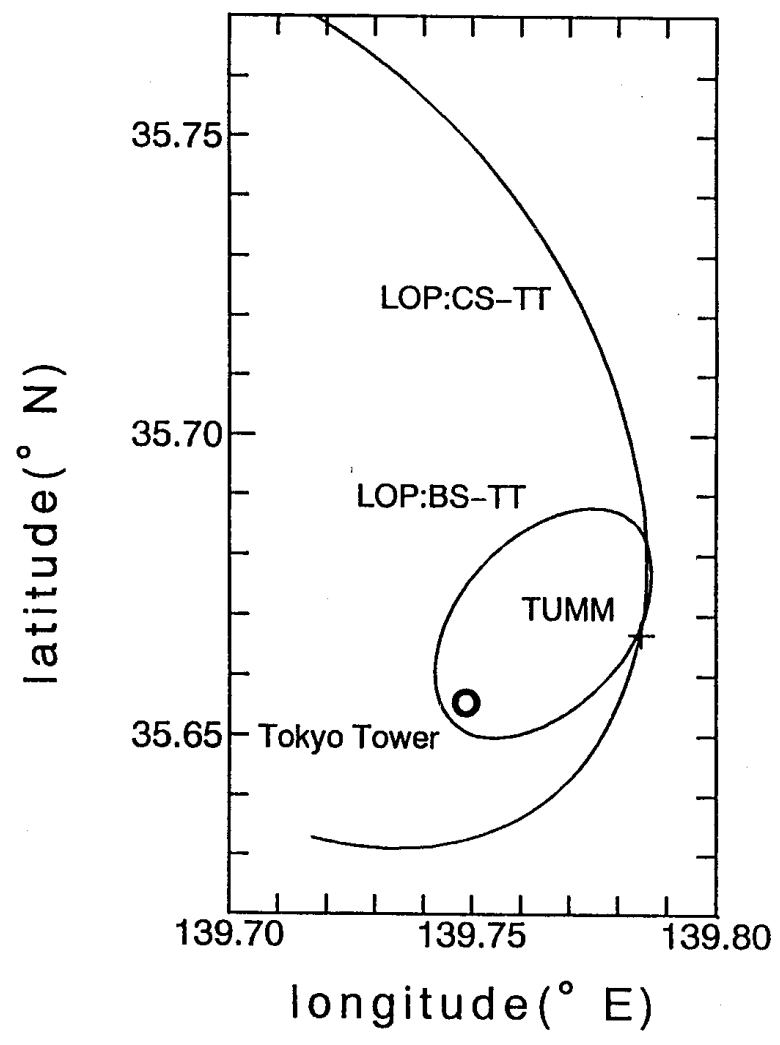

図 5 東京商船大学付近の位置の線

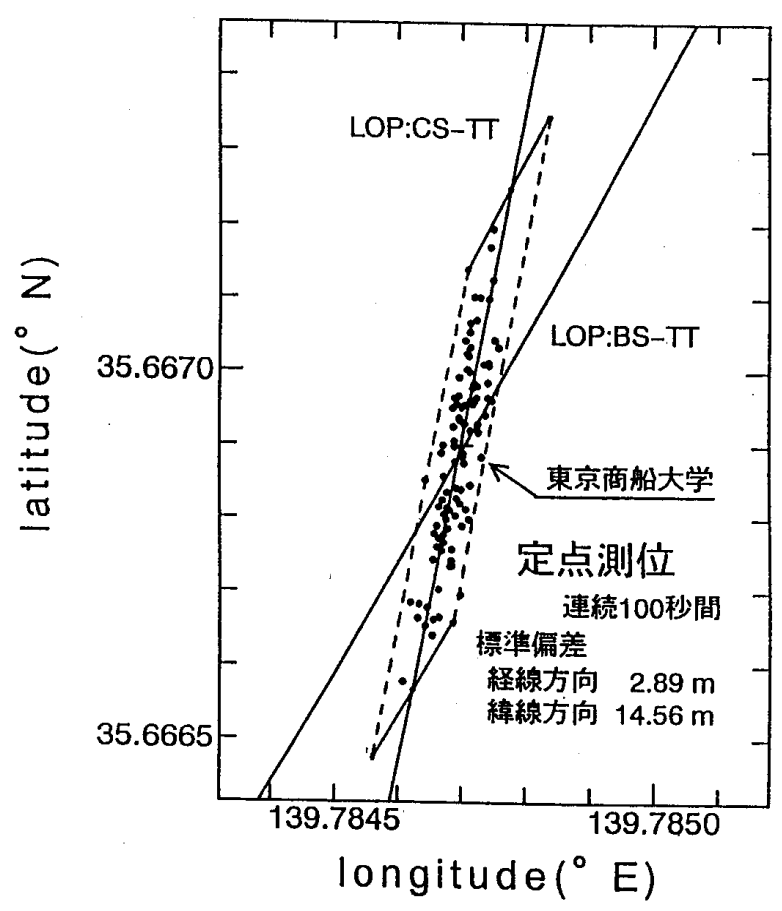

図 6 定点 (東京商船大学)における測位分布

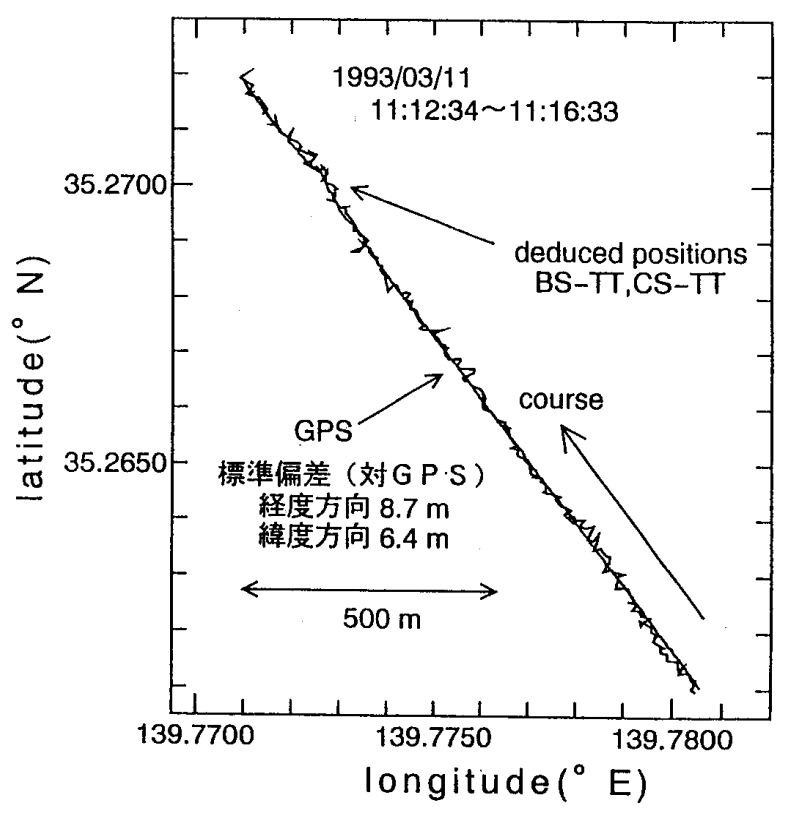

図 7 航跡図 (中ノ瀬航路北上中)

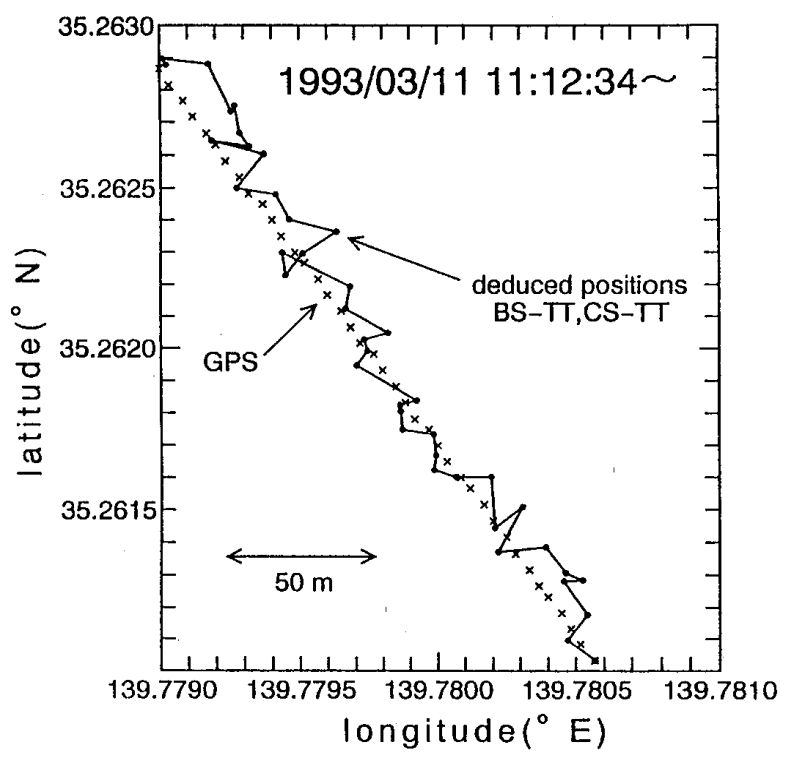

図 8 航跡の拡大 (初期位置から 40 秒間) 図

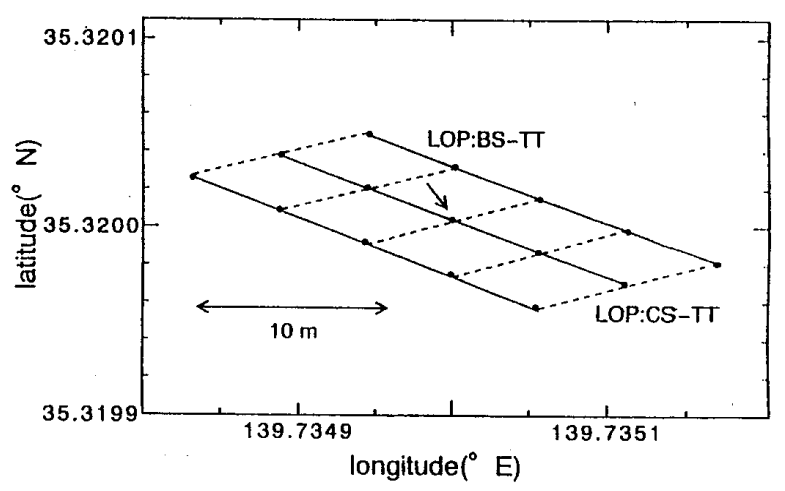

図 9 測位地点付近の位置の線 


\section{7. あとがき}

$\mathrm{BS}\left(110^{\circ} \mathrm{E}\right), \mathrm{CS}\left(\right.$ スーパーバートーB, $\left.162^{\circ} \mathrm{E}\right), \mathrm{VHF}$ (東京タワー)のテレビジョン映像信号を用いた測 位システムを構成し、汐路丸において東京湾上で測位実験を行った。以上の組合わせでは、東京タワー周 辺では位置の線の交角が小さく精度が悪いが、東京湾や相模湾では良い精度の測位が期待できる。

定点の観測では、経度方向の誤差の標準偏差が $3 \mathrm{~m}$ 以下であり、交角さえ良ければ、この程度の測位精 度は得られるものと思われる。

GPS との比較では、差の標準偏差が大きかったが GPS の測位結果に問題がある可能性がある。

2 衛星では、测位可能領域が日本近海まで大幅に拡がり、しかも位置の線の交角が良いので、かなりの 高精度測位が期待できる。最近では、船舶用の衛星放送受信装置はかなり小型で簡便なすのが市販され、 $\mathrm{R}_{\mathrm{b}}$ 発振器もかなり低廉なものが入手できるようになってきている。近い将来テレビ放送を楽しみながら、 高精度の測位が可能になるかも知れない。

高精度測位の為には測距の精度を上げる必要がある。信号処理回路の改良を試み、さらに測距精度向上 を目指したい。

\section{参 考 文 献}

（1） 横井時彦，高橋英博「単一静止衛星を用いた移動体測位方式の提案」，信学技報 SANE89-25，1989 年 8 月

（2）森川栄久他「二つの静止衛星を用いた通信・測位複合システム」，電子情報通信学会論文誌 B一II， V76-B-II，NO.9，pp.735 745，1993 年 9 月

(3) 朱 萍, 安田明生, 山下晃司, 川村雅志「衛星テレビビジョン放送を用いた測位システム」, 日本航 海学会論文集，第 86 号，pp. $65 \sim 73 ， 1992$ 年 3 月

（4）日本放送協会編「放送衛星技術」，日本放送出版協会，pp.191～192，昭和 59 年 6 月

（5）電波航法研究会編「双曲線航法」，海文堂出版，pp. 2 14，昭和 52 年 3 月

(6) 千葉 元, 安田明生他「船舶における衛星放送の受信に関する研究」, 日本航海学会論文集, 第 81 号, pp. 39 48, 平成元年 9 月

\section{質 疑 応 答}

河合雅司 (富山商船高等専門学校) : 東京商船大学における測位精度が非常に良い様に思いますが、測位 計算にあたって衛星，東京タワーまでの生の測距值を用いているか、それとも平均值を用いているのか、 お聞かせ下さい。

安田明生：本文中にあ記載していますが、測位計算にあたっては、1 秒間 (監視データ 15 個, 測距データ 10 個)を平均したあのを用いました。ただし、連続したデータで 2 カウント以上ジャンプしたものは除 いています。 